\title{
Phase Equilibrium Relationships in the System $\mathrm{Gd}_{2} \mathrm{O}_{3}-\mathrm{TiO}_{2}$
}

\author{
J. L. Waring and S. J. Schneider
}

(February 19, 1965)

\begin{abstract}
The phase equilibrium relationships for a major portion of the $\mathrm{Gd}_{2} \mathrm{O}_{3}-\mathrm{TiO}_{2}$ system were determined in air, from a study of solid state reactions and from fusion characteristics. Three intermediate phases, a 1:2 compound, a 1:1 compound, and a face-centered cubic solid solution occur in the system. The solid solution phase is indicated on the phase diagram as existing from 33 to 40 mole percent $\mathrm{TiO}_{2}$, at $1750{ }^{\circ} \mathrm{C}$. This phase melts incongruently over a range of temperatures and compositions, from $1840{ }^{\circ} \mathrm{C}$, the peritectic temperature at 35 mole percent $\mathrm{TiO}_{2}$, to $1775{ }^{\circ} \mathrm{C}$ at 40 mole percent $\mathrm{TiO}_{2}$, the incongruent melting temperature of $\mathrm{Gd}_{2} \mathrm{O}_{3} \cdot \mathrm{TiO}_{2}$. The minimum temperature of stability for the phase is $1600{ }^{\circ} \mathrm{C}$ at 38 mole percent $\mathrm{TiO}_{2}$. The compound $\mathrm{Gd}_{2} \mathrm{O}_{3} \cdot 2 \mathrm{TiO}_{2}$ has a cubic pyrochlore structure type with $a=10.181 \AA$ and melts congruently at $1820^{\circ} \mathrm{C}$. This phase apparently accepts up to about 3 mole percent $\mathrm{TiO}_{2}$ in solid solution at $1460{ }^{\circ} \mathrm{C}$. The compound $\mathrm{Gd}_{2} \mathrm{O}_{3} \cdot \mathrm{TiO}_{2}$, melts incongruently at $1775{ }^{\circ} \mathrm{C}$ and has a reversible phase transition at $1712{ }^{\circ} \mathrm{C}$. The x-ray powder diffraction pattern of the high temperature modification was indexed on the basis of a hexagonal cell $a=3.683 \AA, c=11.995 \AA$ and is apparently related to the A-type rare earth oxide. The compositions $\mathrm{Sm}_{2} \mathrm{O}_{3}: \mathrm{TiO}_{2}$ and $\mathrm{Eu}_{2} \mathrm{O}_{3}: \mathrm{TiO}_{2}$ gave x-ray diffraction powder patterns with marked similarity one to the other as well as to both the high and low polymorphs of $\mathrm{Gd}_{2} \mathrm{O}_{3} \cdot \mathrm{TiO}_{2}$. The composition $\mathrm{Dy}_{2} \mathrm{O}_{3}: \mathrm{TiO}_{2}$ formed several phases one of which is apparently related to the high temperature polymorph of $\mathrm{Gd}_{2} \mathrm{O}_{3} \cdot \mathrm{TiO}_{2}$.
\end{abstract}

\section{Introduction}

The increased availability of more pure rare earth oxides together with a continuing search for new rare earth refractory materials with desirable optical, electrical, and magnetic properties has served as an impetus to investigate the phase equilibrium relationships in rare earth oxide systems. The authors [1] ${ }^{1}$ outlined, in part, the subsolidus relationships of the binary combinations of the rare earth sesquioxides with selected oxides of the trivalent cations.

It was decided to extend this rare earth sesquioxide study to incorporate the oxides of the tetravalent cations. For this reason, the system $\mathrm{Gd}_{2} \mathrm{O}_{3}-\mathrm{TiO}_{2}$ was selected to be studied in detail in air since it is probably representative of other B-type rare earth oxide- $\mathrm{TiO}_{2}$ systems. The only detailed $\mathrm{Ln}_{2} \mathrm{O}_{3}-\mathrm{TiO}_{2}$ phase study ${ }^{2}$ reported previously in the literature was that of the system $\mathrm{La}_{2} \mathrm{O}_{3}-\mathrm{TiO}_{2}$ by MacChesney and Sauer [2]. Roth [3] and Brixner [4] reported the existence of a number of rare earth titanates of the general type $\mathrm{Ln}_{2} \mathrm{Ti}_{2} \mathrm{O}_{7}$ having the pyrochlore type structure, i.e., $\mathrm{Gd}_{2}{ }^{2} \mathrm{Ti}_{2} \mathrm{O}_{7}{ }_{7}^{7}(a=10.181 \AA)$. Queyroux [5] reported a tentative phase diagram for the system $\mathrm{Gd}_{2} \mathrm{O}_{3}-\mathrm{TiO}_{2}$ in which three phases were postulated: a solid solution

${ }^{1}$ Figures in brackets indicate the literature references at the end of the paper.

${ }^{2}$ The symbol "Ln" represents the lanthanide series, lanthanum through lutecum. phase occurring at approximately 40 mole percent $\mathrm{TiO}_{2}$, a $1: 2$ compound with limited solid solution, and a $1: 1$ compound.

Three polymorphs of $\mathrm{Gd}_{2} \mathrm{O}_{3}$ have been reported. They are the $\mathrm{A}$ (hexagonal), $\mathrm{B}$ (monoclinic) and $\mathrm{C}$ (cubic) type rare earth oxides. The A type was reported [6] to occur metastably. Several workers $[7,8]$ have reported that the $\mathrm{C}$ to $\mathrm{B}$ phase transition in $\mathrm{Gd}_{2} \mathrm{O}_{3}$ is reversible. Roth and Schneider [6] concluded that $\mathrm{Gd}_{2} \mathrm{O}_{3}$ crystallizes in the $\mathrm{C}$ form at low temperatures and transforms irreversibly to the $\mathrm{B}$ type at $1225^{\circ} \mathrm{C}$. In this study the B type was considered to be the only stable modification. The unit cell dimensions of $\mathrm{B}$-type $\mathrm{Gd}_{2} \mathrm{O}_{3}$ were reported by Roth and Schneider [6] as $a=14.06 \AA, b=3.572 \AA$, $c=8.75 \AA$, and $\beta=100.10^{\circ}$. Those of $\mathrm{TiO}_{2}$ (rutile) were given by Swanson and Tatge [9] as $a=4.594 \AA$, $c=2.958 \AA$.

\section{Materials}

The starting materials used in this study were found by general quantitative spectrochemical analyses ${ }^{3}$ to have the following impurities: $\mathrm{Gd}_{2} \mathrm{O}_{3}-\mathrm{Ca}$ present in amounts less than 0.01 percent, $\mathrm{Fe}, \mathrm{Mg}, \mathrm{Pb}$, and $\mathrm{Si}$ each present in amounts less than 0.001 percent,

\footnotetext{
${ }^{3}$ The spectrochemical analyses were performed by the Spectrochemical Section of the National Bureau of Standards. The rare earth oxides used to synthesize the related phases were better than 99.7 percent pure.
} 
and $\mathrm{B}, \mathrm{Cu}$, and $\mathrm{Mn}$ each present in amounts less than 0.0001 percent. $\mathrm{TiO}_{2}-\mathrm{Si}$ present in amounts less than .1 percent, $\mathrm{Mg}$ present in amounts less than 0.01 percent, $\mathrm{Cu}$ present in less than 0.001 percent, and $\mathrm{Ca}$ present in amounts less than 0.0001 percent.

\section{Specimen Preparation and Test Methods}

Two gram batches of various combinations of $\mathrm{Gd}_{2} \mathrm{O}_{3}$ and $\mathrm{TiO}_{2}$ were weighed, mixed in a mechanical shaker for approximately $10 \mathrm{~min}$ and pressed into disks at about $10^{4}$ psi. The disks were placed on platinum setters and calcined in air at $1000{ }^{\circ} \mathrm{C}$ for $18 \mathrm{hrs}$. To achieve physical homogeneity the specimens were ground in an agate mortar, repressed and recalcined for an additional $4 \mathrm{hrs}$ at $1000{ }^{\circ} \mathrm{C}$. Following these preliminary heat treatments portions of the ground specimen were placed in platinum alloy tubes and heated in the quenching furnace to various temperatures for different periods of time.

The tubes containing the specimens were quenched into ice water and examined by $\mathrm{x}$-ray diffraction techniques. A high-angle recording Geiger counter diffractometer and Ni-filtered $\mathrm{Cu}$ radiation was used in the study. The Geiger counter traversed the specimen at $1 / 4 \mathrm{deg} / \mathrm{min}$ and radiation was recorded on the chart at $1 \mathrm{deg}-2 \theta / \mathrm{in}$. The unit cell dimensions reported can be considered accurate to about \pm 2 in the last decimal place listed. Equilibrium was considered to have been achieved when x-ray patterns showed no change after successive heat treatments of a specimen or when the data were consistent with the results from a previous set of experiments. Solidus and liquidus temperatures were obtained by using both a quenching furnace and an induction furnace. Because of the temperature limitation of the quenching furnace melting points above $1800^{\circ} \mathrm{C}$ were determined with the induction furnace. Some duplicate determinations below $1800{ }^{\circ} \mathrm{C}$ were made using both furnace types.

The essential features of the furnaces were described previously by the authors [11]. In essence, the quenching furnace consisted of two concentric ceramic tubes wound with platinum-rhodium alloy wire. The inner tube served as the primary winding and the outer one as the booster. Separate power sources were used with each winding.

The power for the outer winding (booster) was supplied from a variable auto transformer. An a-c bridge type controller [12] in which the furnace winding was one arm of the bridge was used to control the temperature of the inner winding. The furnace temperature was controlled to about $\pm 3{ }^{\circ} \mathrm{C}$. Temperature was measured with a 95 percent $\mathrm{Pt}-5$ percent $\mathrm{Rh}$ versus 80 percent $\mathrm{Pt}-20$ percent $\mathrm{Rh}$ thermocouple used in conjunction with a high precision potentiometer.

The induction furnace consisted of an iridium crucible and cover which acted as the susceptor and specimen container. A small fragment of the calcined material was placed in the iridium crucible on an iridium setter or button and heated to the desired temperature for about $2 \mathrm{~min}$ to achieve thermal equilibrium. Apparent temperatures were measured with a calibrated, disappearing filament-type optical pyrometer which was sighted through a $45 \mathrm{deg}$ calibrated prism into the viewing hole at the center of the crucible cover. The temperature measuring system of both the quenching furnace and the induction furnace were calibrated frequently against the melting point of $\mathrm{Au}\left(1063{ }^{\circ} \mathrm{C}\right), \mathrm{Pd}\left(1552{ }^{\circ} \mathrm{C}\right)$, and $\mathrm{Pt}\left(1769^{\circ} \mathrm{C}\right)^{4}$. In addition, the measuring system of the induction furnace was also calibrated against the melting point of $\mathrm{Rh}\left(1960^{\circ} \mathrm{C}\right)$. Temperatures reported in the present study were considered accurate to within $\pm 10{ }^{\circ} \mathrm{C}$ below $1650{ }^{\circ} \mathrm{C}$ and to within $\pm 20{ }^{\circ} \mathrm{C}$ above. The measurements were reproducible to within $\pm 5{ }^{\circ} \mathrm{C}$, or better. The degree of melting was determined by the physical appearance of quenched or rapidly cooled specimens. The first adherence of the specimen to the platinum container or iridium setter generally established the beginning of melting. In quenched specimens, complete melting was established by the formation of a meniscus. Similarly the slumping or loss of shape of the inductively heated specimens established complete melting.

\section{Results and Discussion}

The equilibrium phase diagram (fig. 1) for a major portion of the $\mathrm{Gd}_{2} \mathrm{O}_{3}-\mathrm{TiO}_{2}$ system has been constructed from the data listed in tables 1 and 2 . Solid circles represent composition and temperatures of experiments conducted in the quenching furnace and solid triangles represent those conducted in the induction furnace. A combination of a solid triangle bound by an open circle represents those conducted in both types of furnaces at the same temperature. Two melting points of $\mathrm{Gd}_{2} \mathrm{O}_{3} 2330{ }^{\circ} \mathrm{C}$ and $2350{ }^{\circ} \mathrm{C}[13$, 14] have been reported. Because of the temperature limitations of the present equipment the value was not redetermined. The numerous reported melting points of $\mathrm{TiO}_{2}$ have been tabulated by Schneider [15]. Because of the apparent problems inherent with the determination of the melting point of $\mathrm{TiO}_{2}$, a redetermination was not made at this time.

The following intermediate phases, indicated in figure 1, were found to occur in the system: a solid solution $\left(\mathrm{FCC}_{\mathrm{ss}}\right)$, existing at about $1750{ }^{\circ} \mathrm{C}$, from approximately 33 to 40 mole percent $\mathrm{TiO}_{2}$; a compound, $\mathrm{Gd}_{2} \mathrm{O}_{3} \cdot \mathrm{TiO}_{2}$, and a compound $\mathrm{Gd}_{2} \mathrm{O}_{3} \cdot 2 \mathrm{TiO}_{2}$. These data generally confirm those reported by Queyroux [5].

The solid solution phase $\left(\mathrm{FCC}_{\mathrm{ss}}\right)$ has a maximum incongruent melting point at $1840{ }^{\circ} \mathrm{C}$ at 35 mole percent $\mathrm{TiO}_{2}$. A minimum dissociation temperature was found to occur at $1600{ }^{\circ} \mathrm{C}$ at 38 mole percent $\mathrm{TiO}_{2}$ as compared to the $1550{ }^{\circ} \mathrm{C}$ [5] value reported previously. The existence of a minimum decomposition temperature was evident since the solid solution phase once

${ }^{4}$ The purity of the metals used for calibration purposes was better than 99.9 percent. See reference [10]. 
formed could be decomposed by reheating to 1548 ${ }^{\circ} \mathrm{C}$ for $4 \mathrm{hrs}$. From x-ray powder diffraction data, the solid solution phase was shown to be face-centered cubic with a maximum unit cell dimension of $5.32 \AA$ and a minimum of $5.28 \AA$ at $1750{ }^{\circ} \mathrm{C}$. Since the x-ray patterns were of rather poor quality with characteristic high background, the polarizing microscope was employed to determine the compositional limits of the phase. Small amounts of anisotropic phases were easily distinguished from the isotropic cubic phase.

The compound, $\mathrm{Gd}_{2} \mathrm{O}_{3} \cdot \mathrm{TiO}_{2}$, was found to melt incongruently at $1775^{\circ} \mathrm{C}$ and to have a reversible phase transition at $1712{ }^{\circ} \mathrm{C}$. The $\mathrm{x}$-ray powder diffraction patterns for the low and the high temperature polymorphs of the $1: 1$ compound are given in tables 3 and
4 respectively. Unfortunately, neither of the x-ray patterns of the polymorphs of $\mathrm{Gd}_{2} \mathrm{O}_{3} \cdot \mathrm{TiO}_{2}$ could be indexed on a unit cell based on the constants given by Queyroux [5]. Without a more complete reporting of Queyroux's data these discrepancies cannot be resolved. The x-ray diffraction powder pattern of the low temperature form $\left(\mathrm{L}-\mathrm{Gd}_{2} \mathrm{O}_{3} \cdot \mathrm{TiO}_{2}\right)$ was not indexed. However, the $\mathrm{x}$-ray diffraction pattern of the high temperature form $\left(\mathrm{H}-\mathrm{Gd}_{2} \mathrm{O}_{3} \cdot \mathrm{TiO}_{2}\right)$ was indexed on the basis of a hexagonal cell, $a=3.683 \AA$, $c=11.995 \AA$. The high temperature polymorph is apparently related to the hexagonal A-type rare earth oxide through the relationship $c$ (hexagonal $\mathrm{Ln}_{2} \mathrm{O}_{3}$ ) $\cong \frac{1}{2} c\left(\mathrm{H}-\mathrm{Gd}_{2} \mathrm{O}_{3} \cdot \mathrm{TiO}_{2}\right)$. Some difficulty was encountered in determining the inversion temperature since

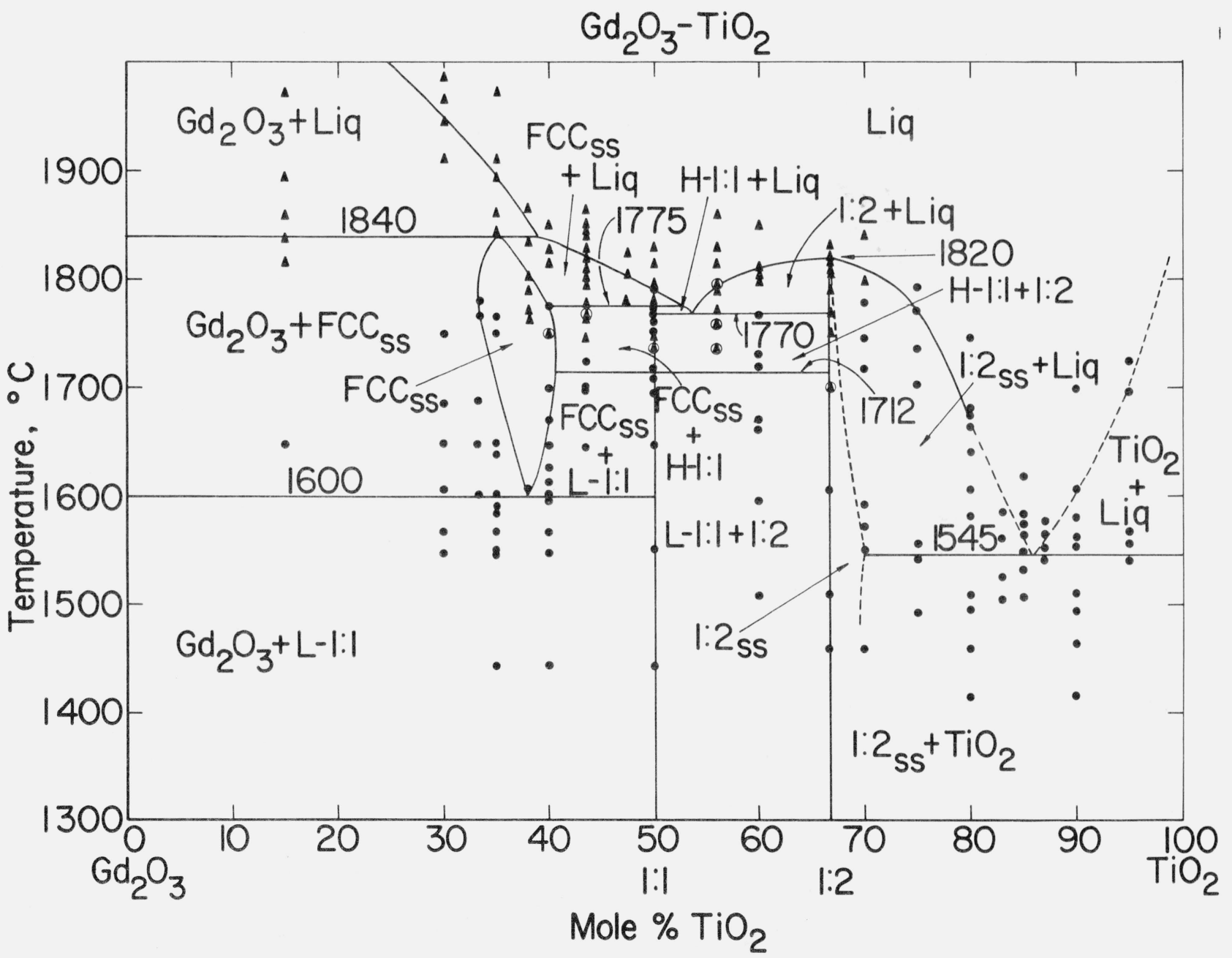

FIgURE 1. Phase equilibrium diagram for the system $\mathrm{Gd}_{2} \mathrm{O}_{3}-\mathrm{TiO}_{2}$.

$\mathrm{L}-1: 1$ - Low temperature form of $\mathrm{Gd}_{2} \mathrm{O}_{3}$. $\mathrm{TiO}_{2}$.

$\mathrm{H}-1: 1$ - High temperature form of $\mathrm{Gd}_{2} \mathrm{O}_{3} \cdot \mathrm{TiO}_{2}$

1:2 $-\mathrm{Gd}_{2} \mathrm{O}_{3} \cdot 2 \mathrm{TiO}_{2}$.

FCC - Face centered cubic phase.

ss - Solid solution.

Liq - Liquid.

- Compositions and temperatures of experiments conducted in the quench furnace.

- Compositions and temperatures of experiments conducted in the iridium crucible induction furnace.

- Compositions and temperatures of experiments conducted in both the quenching and induction furnace.

For clarity, not all experimental data appearing in tables 1 and 2 are plotted on this diagram. 
TABLE 1. Experimental quenching data for compositions in the $\mathrm{Gd}_{2} \mathrm{O}_{3}-\mathrm{TiO}_{2}$ system

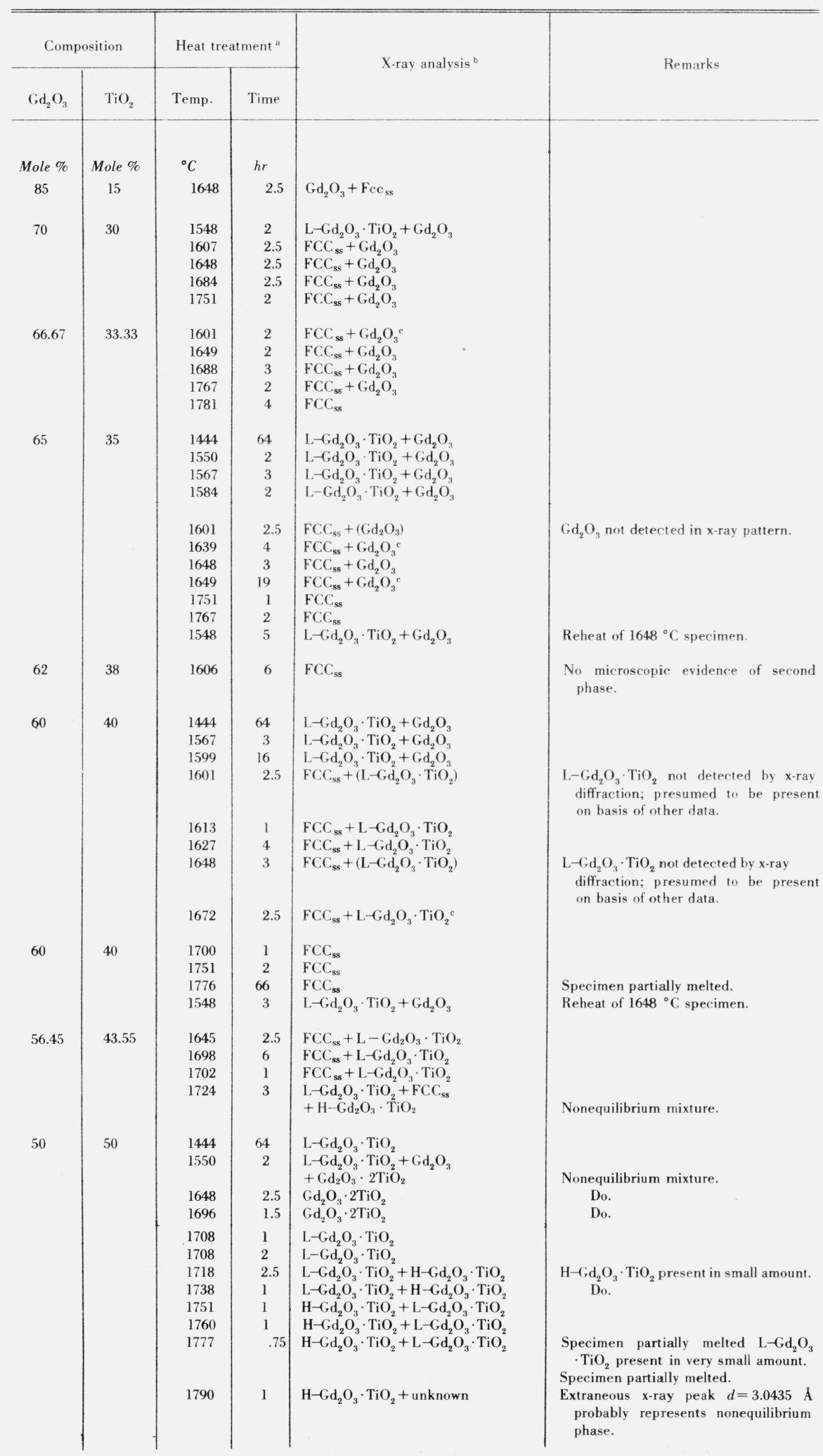


TABLE 1. Experimental quenching datafor compositions in the $\mathrm{Gd}_{2} \mathrm{O}_{3}-\mathrm{TiO}_{2}$ system-Continued .

\begin{tabular}{|c|c|c|c|c|c|}
\hline \multicolumn{2}{|c|}{ Composition } & \multicolumn{2}{|c|}{ Heat treatment ${ }^{a}$} & \multirow{2}{*}{ X-ray analysis ${ }^{b}$} & \multirow{2}{*}{ Remarks } \\
\hline $\mathrm{Gd}_{2} \mathrm{O}_{3}$ & $\mathrm{TiO}_{2}$ & Temp. & Time & & \\
\hline Mole \% & Mole \% & $\begin{array}{l}{ }^{\circ} \mathrm{C} \\
1652 \\
1754\end{array}$ & $\begin{array}{c}h r \\
7 \\
5\end{array}$ & $\begin{array}{l}\mathrm{L}-\mathrm{Gd}_{2} \mathrm{O}_{3} \cdot \mathrm{TiO}_{2} \\
\mathrm{H}-\mathrm{Gd}_{2} \mathrm{O}_{3} \cdot \mathrm{TiO}_{2}+\mathrm{L}-\mathrm{Gd}_{2} \mathrm{O}_{3} \cdot \mathrm{TiO}_{2}\end{array}$ & $\begin{array}{l}\text { Reheat of } 1777^{\circ} \mathrm{C} \text { specimen. } \\
\text { Reheat of } 1790^{\circ} \mathrm{C} \text { specimen. }\end{array}$ \\
\hline 44 & 56 & $\begin{array}{l}1737 \\
1762\end{array}$ & $\begin{array}{c}3.5 \\
.33\end{array}$ & $\begin{array}{l}\mathrm{H}-\mathrm{Gd}_{2} \mathrm{O}_{3} \cdot \mathrm{TiO}_{2}+\mathrm{Gd}_{2} \mathrm{O}_{3} \cdot 2 \mathrm{TiO}_{2} \\
\mathrm{H}-\mathrm{Gd}_{2} \mathrm{O}_{3} \cdot \mathrm{TiO}_{2}+\mathrm{Gd}_{2} \mathrm{O}_{3} \cdot 2 \mathrm{TiO}_{2}\end{array}$ & \\
\hline 40 & 60 & $\begin{array}{l}1508 \\
1597 \\
1662 \\
1670 \\
1720 \\
1730\end{array}$ & $\begin{array}{l}3 \\
2 \\
5 \\
4 \\
3.5 \\
1.5\end{array}$ & $\begin{array}{l}\mathrm{L}-\mathrm{Gd}_{2} \mathrm{O}_{3} \cdot \mathrm{TiO}_{2}+\mathrm{Gd}_{2} \mathrm{O}_{3} \cdot 2 \mathrm{TiO}_{2} \\
\mathrm{~L}-\mathrm{Gd}_{2} \mathrm{O}_{3} \cdot \mathrm{TiO}_{2}+\mathrm{Gd}_{2} \mathrm{O}_{3} \cdot 2 \mathrm{TiO}_{2} \\
\mathrm{~L}-\mathrm{Cd}_{2} \mathrm{O}_{3} \cdot \mathrm{TiO}_{2}+\mathrm{Gd}_{2} \mathrm{O}_{3} \cdot 2 \mathrm{TiO}_{2} \\
\mathrm{~L}-\mathrm{Cd}_{2} \mathrm{O}_{3} \cdot \mathrm{TiO}_{2}+\mathrm{Gd}_{2} \mathrm{O}_{3} \cdot 2 \mathrm{TiO}_{2} \\
\mathrm{Gd}_{2} \mathrm{O}_{3} \cdot 2 \mathrm{TiO}_{2}+\mathrm{H}-\mathrm{Gd}_{2} \mathrm{O}_{3} \cdot \mathrm{TiO}_{2} \\
\mathrm{Gd}_{2} \mathrm{O}_{3} \cdot 2 \mathrm{TiO} \\
\end{array}$ & \\
\hline 33.33 & 66.67 & $\begin{array}{l}1460 \\
1508 \\
1604 \\
1702\end{array}$ & $\begin{array}{l}19 \\
1 \\
0.5 \\
2\end{array}$ & $\begin{array}{l}\mathrm{Gd}_{2} \mathrm{O}_{3} \cdot 2 \mathrm{TiO}_{2} \\
\mathrm{Gd}_{2} \mathrm{O}_{3} \cdot 2 \mathrm{TiO}_{2} \\
\mathrm{Gd}_{2} \mathrm{O}_{3} \cdot 2 \mathrm{TiO}_{2} \\
\mathrm{Gd}_{2} \mathrm{O}_{3} \cdot 2 \mathrm{TiO}_{2}\end{array}$ & \\
\hline 30 & 70 & 1460 & 19 & $\mathrm{Gd}_{2} \mathrm{O}_{3} \cdot 2 \mathrm{TiO}_{2 \mathrm{ss}}+\mathrm{TiO}_{2}$ & \\
\hline 20 & 80 & $\begin{array}{l}1416 \\
1460\end{array}$ & $\begin{array}{l}25 \\
19\end{array}$ & $\begin{array}{l}\mathrm{Gd}_{2} \mathrm{O}_{3} \cdot 2 \mathrm{TiO}_{2 \mathrm{ss}}+\mathrm{TiO}_{2} \\
\mathrm{Gd}_{2} \mathrm{O}_{3} \cdot 2 \mathrm{TiO}_{2 \mathrm{ss}}+\mathrm{TiO}_{2}\end{array}$ & \\
\hline 10 & 90 & 1416 & 25 & $\mathrm{TiO}_{2}+\mathrm{Gd}_{2} \mathrm{O}_{3} \cdot 2 \mathrm{TiO}_{2} \mathrm{ss}$ & \\
\hline
\end{tabular}

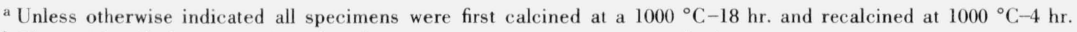

${ }^{b}$ Phases identified are given in order of amount present (greatest amount first) at room temperature.

c Second phase identified by use of petrographic microscope.

TABLE 2. Melting characteristics of the $\mathrm{Gd}_{2} \mathrm{O}_{3}-\mathrm{TiO}_{2}$ system

\begin{tabular}{|c|c|c|c|c|}
\hline \multicolumn{2}{|c|}{ Composition a } & \multirow{2}{*}{ Temperature ${ }^{b}$} & \multirow{2}{*}{ Furnace ${ }^{c}$} & \multirow{2}{*}{ Observation } \\
\hline $\mathrm{Gd}_{2} \mathrm{O}_{3}$ & $\mathrm{TiO}_{2}$ & & & \\
\hline Mole \% & Mole \% & ${ }^{\circ} \mathrm{C}$ & & \\
\hline 85 & 15 & $\begin{array}{l}1816 \\
1839 \\
1860 \\
1897 \\
1974\end{array}$ & $\begin{array}{l}\text { I } \\
\text { I } \\
\text { I } \\
\text { I } \\
\text { I }\end{array}$ & $\begin{array}{l}\text { Not melted. } \\
\text { Do. } \\
\text { Partially melted. } \\
\text { Do. } \\
\text { Do. }\end{array}$ \\
\hline 70 & 30 & $\begin{array}{l}1911 \\
1946 \\
1967 \\
1987\end{array}$ & $\begin{array}{l}\text { I } \\
\text { I } \\
\text { I } \\
\text { I }\end{array}$ & $\begin{array}{l}\text { Do. } \\
\text { Do. } \\
\text { Completely melted. } \\
\text { Do. }\end{array}$ \\
\hline 65 & 35 & $\begin{array}{l}1838 \\
1841 \\
1845 \\
1862 \\
1894 \\
1911 \\
1974\end{array}$ & $\begin{array}{l}\text { I } \\
\text { I } \\
\text { I } \\
\text { I } \\
\text { I } \\
\text { I } \\
\text { I }\end{array}$ & $\begin{array}{l}\text { Not melted. } \\
\text { Partially melted. } \\
\text { Do. } \\
\text { Do. } \\
\text { Completely melted. } \\
\text { Do. } \\
\text { Do. }\end{array}$ \\
\hline 62 & 38 & $\begin{array}{l}1765 \\
1773 \\
1790 \\
1804 \\
1835 \\
1867\end{array}$ & $\begin{array}{l}\text { I } \\
\text { I } \\
\text { I } \\
\text { I } \\
\text { I } \\
\text { I }\end{array}$ & $\begin{array}{l}\text { Not melted. } \\
\text { Do. } \\
\text { Do. } \\
\text { Partially melted. } \\
\text { Do. } \\
\text { Completely melted. }\end{array}$ \\
\hline 60 & 40 & $\begin{array}{l}1751 \\
1776 \\
1816 \\
1829 \\
1850\end{array}$ & $\begin{array}{l}\text { Q } \\
Q \\
\text { I } \\
\text { I } \\
\text { I }\end{array}$ & $\begin{array}{l}\text { Not melted. } \\
\text { Partially melted. } \\
\text { Do. } \\
\text { Do. } \\
\text { Completely melted. }\end{array}$ \\
\hline 56.45 & 43.55 & $\begin{array}{l}1745 \\
1765 \\
1768 \\
1779 \\
1796 \\
1803 \\
1811\end{array}$ & $\begin{array}{l}\text { I } \\
\text { I } \\
\text { I } \\
\text { I } \\
\text { I } \\
\text { I } \\
\text { I }\end{array}$ & $\begin{array}{l}\text { Not melted. } \\
\text { Do. } \\
\text { Do. } \\
\text { Partially melted. } \\
\text { Do. } \\
\text { Do. } \\
\text { Do. }\end{array}$ \\
\hline
\end{tabular}

TABLE 2. Melting characteristics of the $\mathrm{Gd}_{2} \mathrm{O}_{3}-\mathrm{TiO}_{2}$ system-Con.

\begin{tabular}{|c|c|c|c|c|}
\hline \multicolumn{2}{|c|}{ Composition a } & \multirow{2}{*}{ Temperature ${ }^{b}$} & \multirow{2}{*}{ Furnace $^{c}$} & \multirow{2}{*}{ Observation } \\
\hline $\mathrm{Gd}_{2} \mathrm{O}_{3}$ & $\mathrm{TiO}_{2}$ & & & \\
\hline \multirow[t]{3}{*}{ Mole \% } & Mole \% & ${ }^{\circ} \mathrm{C}$ & & \\
\hline & & $\begin{array}{l}1821 \\
1830\end{array}$ & $\begin{array}{l}\text { I } \\
\text { I }\end{array}$ & $\begin{array}{l}\text { Completely melted } \\
\text { Do. }\end{array}$ \\
\hline & & $\begin{array}{l}1841 \\
1849 \\
1853 \\
1866\end{array}$ & $\begin{array}{l}\text { I } \\
\text { I } \\
\text { I } \\
\text { I }\end{array}$ & $\begin{array}{l}\text { Completely melted. } \\
\text { Do. } \\
\text { Do. } \\
\text { Do. }\end{array}$ \\
\hline 52.60 & 47.40 & $\begin{array}{l}1780 \\
1805 \\
1824\end{array}$ & $\begin{array}{l}\text { I } \\
\text { I } \\
\text { I }\end{array}$ & $\begin{array}{l}\text { Partially melted. } \\
\text { Completely melted. } \\
\text { Do. }\end{array}$ \\
\hline 50 & 50 & $\begin{array}{l}1772 \\
1777 \\
1779 \\
1782 \\
1795 \\
1790 \\
1814 \\
1832\end{array}$ & $\begin{array}{l}Q \\
Q \\
I \\
Q \\
I \\
Q \\
I \\
I\end{array}$ & $\begin{array}{l}\text { Not melted. } \\
\text { Partially melted. } \\
\text { Do. } \\
\text { Do. } \\
\text { Completely melted. } \\
\text { Do. } \\
\text { Do. } \\
\text { Do. }\end{array}$ \\
\hline 44 & 56 & $\begin{array}{l}1737 \\
1762 \\
1762 \\
1773 \\
1790 \\
1796 \\
1797 \\
1813 \\
1830 \\
1862 \\
1996 \\
2050\end{array}$ & $\begin{array}{l}\text { I } \\
Q \\
\text { I } \\
\text { I } \\
\text { I } \\
\text { I } \\
Q \\
\text { I } \\
\text { I } \\
\text { I } \\
\text { I } \\
\text { I }\end{array}$ & $\begin{array}{l}\text { Not melted. } \\
\text { Not melted. } \\
\text { Do. } \\
\text { Partially melted. } \\
\text { Do. } \\
\text { Do. } \\
\text { Do. } \\
\text { Completely melted. } \\
\text { Do. } \\
\text { Do. } \\
\text { Do. } \\
\text { Do. }\end{array}$ \\
\hline 40 & 60 & $\begin{array}{l}1767 \\
1799 \\
1806 \\
1813 \\
1849\end{array}$ & $\begin{array}{l}Q \\
\text { I } \\
\text { I } \\
\text { I } \\
\text { I }\end{array}$ & $\begin{array}{l}\text { Not melted. } \\
\text { Partially melted. } \\
\text { Do. } \\
\text { Completely melted. } \\
\text { Do. }\end{array}$ \\
\hline
\end{tabular}


TABLE 2. Melting characteristics of the $\mathrm{Gd}_{2} \mathrm{O}_{3}-\mathrm{TiO}_{2}$ system-Con.

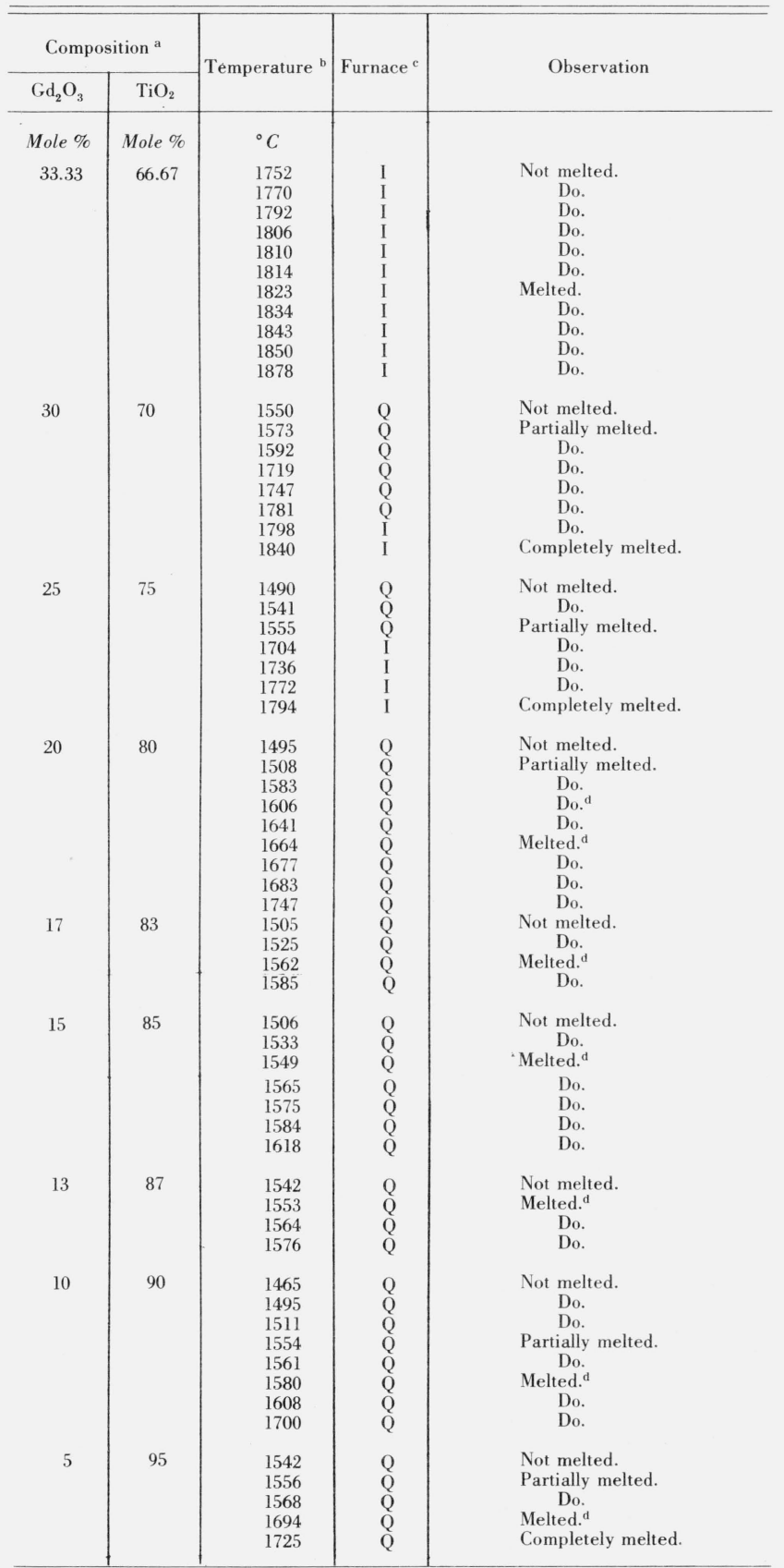

a Specimens first calcined at $1000{ }^{\circ} \mathrm{C}$ for $18 \mathrm{hr}$ and recalcined at $1000{ }^{\circ} \mathrm{C}$ for $4 \mathrm{hr}$. ${ }^{\mathrm{b}}$ Specimens furnace cooled except when indicated.

c Q-quenching furnace; I-induction furnace. All specimens heated in induction furnace slow cooled rather than quenched.

${ }^{d}$ Definite verification of complete melting could not be obtained.

numerous attempts to quench $\mathrm{H}-\mathrm{Gd}_{2} \mathrm{O}_{3} \cdot \mathrm{TiO}_{2}$ as a single phase below the solidus were unsuccessful. In each instance a small amount of $\mathrm{L}-\mathrm{Gd}_{2} \mathrm{O}_{3} \cdot \mathrm{TiO}_{2}$ was present. However, the x-ray pattern of the partially melted $1: 1$ compound quenched from $1790{ }^{\circ} \mathrm{C}$ was found to be essentially single phase. One very weak extra line occurred in the $\mathrm{x}$-ray pattern at $d$ $=3.044 \AA$ which was probably representative of a metastable phase formed only in the quenched liquid. Both the 33.33 and the 43.55 percent $\mathrm{TiO}_{2}$ compositions when quenched from above $1712{ }^{\circ} \mathrm{C}$, the inversion temperature of $\mathrm{Gd}_{2} \mathrm{O}_{3} \cdot \mathrm{TiO}_{2}$, contained $\mathrm{H}-\mathrm{Gd}_{2} \mathrm{O}_{3} \cdot \mathrm{TiO}_{2}$ and an appropriate second phase. The same compositions quenched from below $1712^{\circ} \mathrm{C}$ contained $\mathrm{L}-\mathrm{Gd}_{2} \mathrm{O}_{3}$ $\cdot \mathrm{TiO}_{2}$ and an appropriate second phase. These experimental data seem to indicate that the possibility of quenching $\mathrm{H}-\mathrm{Gd}_{2} \mathrm{O}_{3} \cdot \mathrm{TiO}_{2}$ without residual traces of $\mathrm{L}-\mathrm{Gd}_{2} \mathrm{O}_{3} \cdot \mathrm{TiO}_{2}$ is only accomplished by the presence of another second phase.

Other $\mathrm{Ln}_{2} \mathrm{O}_{3}: \mathrm{TiO}_{2}$ compositions were also studied. From x-ray powder diffraction data, it appears that the compositions $\mathrm{Sm}_{2} \mathrm{O}_{3}: \mathrm{TiO}_{2}$ and $\mathrm{Eu}_{2} \mathrm{O}_{3}: \mathrm{TiO}_{2}$ form phases which are very similar to both $\mathrm{L}-\mathrm{Gd}_{2} \mathrm{O}_{3} \cdot \mathrm{TiO}_{2}$ and $\mathrm{H}-\mathrm{Gd}_{2} \mathrm{O}_{3} \cdot \mathrm{TiO}_{2}$. The composition $\mathrm{Dy}_{2} \mathrm{O}_{3}$ : $\mathrm{TiO}_{2}$ was found to contain a mixture of phases, one of which is apparently similar to $\mathrm{H}-\mathrm{Gd}_{2} \mathrm{O}_{3} \cdot \mathrm{TiO}_{2}$. These related phases were not detected in the equimolar compositions of the oxides of the smaller rare earth cations with $\mathrm{TiO}_{2}$.

The compound $\mathrm{Gd}_{2} \mathrm{O}_{3} \cdot \mathrm{TiO}_{2}$ was found to melt congruently at $1820^{\circ} \mathrm{C}$. From the change in unit cell constants with composition the compound apparently accepted up to about 3 mole percent $\mathrm{TiO}_{2}$ in solid solution. The unit cell dimensions of the compositions $\mathrm{Gd}_{2} \mathrm{O}_{3}: 2 \mathrm{TiO}_{2}$ and $30 \mathrm{Gd}_{2} \mathrm{O}_{3}: 70 \mathrm{TiO}_{2}$ quenched from $1460{ }^{\circ} \mathrm{C}$ are $10.181 \AA$ and $10.169 \AA$, respectively. Since the latter composition contained a small amount of $\mathrm{TiO}_{2}$ the exsolution curve delineating the phase boundary is shown (fig. 1) as dashed at 69 percent $\mathrm{TiO}_{2}$.

Earlier, the present authors [16] reported the parameters of the following $\mathrm{Ln}_{2} \mathrm{O}_{3} \cdot 2 \mathrm{TiO}_{2}$ pyrochlore-type phases: $\quad \mathrm{Eu}_{2} \mathrm{O}_{3} \cdot 2 \mathrm{TiO}_{2} \quad(a=10.195) ; \quad \mathrm{Ho}_{2} \mathrm{O}_{3} \cdot 2 \mathrm{TiO}_{2}$ $(a=10.098 \AA) ; \mathrm{Er}_{2} \mathrm{O}_{3} \cdot 2 \mathrm{TiO}_{2}(a=10.075 \AA) ; \mathrm{Tm}_{2} \mathrm{O}_{3}$

TABLE 3. X-ray diffraction powder data for the low temperature modification of $\mathrm{Gd}_{2} \mathrm{O}_{3} \cdot \mathrm{TiO}_{2}\left(\mathrm{CuK}_{\alpha}\right.$ radiation $)$

\begin{tabular}{c|r}
\hline \hline$d^{\mathrm{a}}$ & \multicolumn{1}{|c}{$I / I_{0}{ }^{\mathrm{b}}$} \\
\hline$\AA$ & \\
7.70 & 21 \\
3.56 & 21 \\
3.066 & 100 \\
3.060 & 79 \\
3.054 & 64 \\
& \\
2.976 & 14 \\
2.947 & 14 \\
2.667 & 64 \\
2.624 & 14 \\
2.566 & 17 \\
& \\
2.554 & 21 \\
2.334 & 11 \\
2.130 & 14 \\
2.113 & 14 \\
1.925 & 14 \\
& \\
1.896 & 10 \\
1.869 & 21 \\
1.661 & 19 \\
1.648 & 10 \\
1.607 & 26 \\
1.601 & 11 \\
1.597 & 43 \\
1.586 & 29 \\
1.583 & 17 \\
1.569 & 14 \\
\hline
\end{tabular}

anterplanar spacing.

${ }^{\mathrm{b}}$ Relative intensity. 
TABLE 4. X-ray diffraction powder data for the high temperature modification of $\mathrm{Gd}_{2} \mathrm{O}_{3} \cdot \mathrm{TiO}_{2}{ }^{\text {a }}\left(\mathrm{CuK}_{\alpha}\right.$ radiation $)$

\begin{tabular}{|c|c|c|c|c|}
\hline \multirow{2}{*}{$h k l^{\mathrm{b}}$} & \multirow{2}{*}{$d^{c}$} & \multicolumn{2}{|c|}{$1 / d^{2}$} & \multirow{2}{*}{$I / I_{0}{ }^{\mathrm{e}}$} \\
\hline & & Obs & $\mathrm{Cal}^{\mathrm{d}}$ & \\
\hline 002 & $\begin{array}{c}\AA \\
6.02\end{array}$ & 0.0276 & 0.0277 & 10 \\
\hline 100 & 3.189 & .0983 & .0983 & 38 \\
\hline \multirow[t]{2}{*}{101} & 3.083 & .1052 & .1056 & 32 \\
\hline & 3.0435 & .1080 & & 10 \\
\hline 004 & 3.007 & .1105 & .1112 & 26 \\
\hline 102 & 2.817 & .1260 & .1264 & 100 \\
\hline 104 & 2.185 & .2094 & .2098 & 22 \\
\hline 105 & 1.918 & .2720 & .2724 & 8 \\
\hline 110 & 1.839 & .2958 & .2958 & 29 \\
\hline 112 & 1.757 & .3239 & .3236 & 8 \\
\hline 106 & 1.694 & .3484 & .3488 & 12 \\
\hline 200 & 1.645 & .3944 & .3944 & 58 \\
\hline 201 & 1.578 & .4017 & .4014 & 10 \\
\hline 114 & 1.568 & .4070 & .4070 & 59 \\
\hline 202 & 1.538 & .4227 & .4222 & 60 \\
\hline 212 & 1.1801 & .7183 & .7181 & 8 \\
\hline 300 & 1.0612 & .8881 & .8875 & 8 \\
\hline
\end{tabular}

Specimen not single phase. The line which occurs at $d=3.0435 \AA$ probably repre sents a metastable phase formed only in the quenched liquid.

${ }^{b}$ Hexagonal Miller indices.

Interplanar Spacing.

Based on a hexagonal cell, $a=3.683 \AA, c=11.995 \AA$.

Relative intensity.

- $2 \mathrm{TiO}_{2}(a=10.055 \AA)$ and $\mathrm{Lu}_{2} \mathrm{O}_{3} \cdot 2 \mathrm{TiO}_{2}(a=10.023 \AA)$. Subsequent work by Brixner [4] confirmed these earlier data.

The eutectic between $\mathrm{Gd}_{2} \mathrm{O}_{3} \cdot 2 \mathrm{TiO}_{2}$ and $\mathrm{TiO}_{2}$ is shown (fig. 1) as occurring at approximately 86 mole percent $\mathrm{TiO}_{2}$. Some difficulty was encountered in establishing the liquidus curves near the eutectic composition because it was virtually impossible to distinguish a partially melted from a completely melted specimen. For this reason, the eutectic composition shown in fig. 1 was approximated. Since the melting point of $\mathrm{TiO}_{2}$ was not redetermined the liquidus was dashed from the eutectic composition to approximately 100 percent $\mathrm{TiO}_{2}$.

\section{Summary}

The phase equilibrium diagram for a major portion of the $\mathrm{Gd}_{2} \mathrm{O}_{3}-\mathrm{TiO}_{2}$ system has been determined from a study of solid state reactions and melting point relations.

A platinum alloy quenching furnace was used to establish all of the subsolidus and some of the liquidus relationships below $1800^{\circ} \mathrm{C}$. An inductively heated iridium crucible was used for the determination of solidus and liquidus relationships above $1800^{\circ} \mathrm{C}$. Phases were identified by x-ray powder diffraction and polarizing microscopic techniques.

Three intermediate phases were formed in the system. A solid solution phase is indicated on the phase diagram as existing from 33 to 40 mole percent $\mathrm{TiO}_{2}$, at $1750{ }^{\circ} \mathrm{C}$. This phase melts incongruently over a range of temperatures and compositions varying from $1840{ }^{\circ} \mathrm{C}$, the peritectic temperature, at 35 mole percent $\mathrm{TiO}_{2}$ to $1775^{\circ} \mathrm{C}$, at 40 mole percent $\mathrm{TiO}_{2}$ the incongruent melting temperature of $\mathrm{Gd}_{2} \mathrm{O}_{3} \cdot \mathrm{TiO}_{2}$. The minimum temperature of stability for the phase is $1600{ }^{\circ} \mathrm{C}$ at 38 mole percent $\mathrm{TiO}_{2}$. The x-ray diffraction pattern of the solid solution phase was indexed on the basis of a face-centered cubic cell with unit cell dimension varying from about $5.28 \AA$ to $5.32 \AA$ at $1750{ }^{\circ} \mathrm{C}$. The second phase, a $1: 1$ compound, melts incongruently at $1775^{\circ} \mathrm{C}$ and has a reversible phase transition at $1712^{\circ} \mathrm{C}$. The high temperature modification was indexed on the basis of a hexagonal cell related to the hexagonal rare earth oxides with $a=3.683 \AA, c=11.995 \AA$. The third phase, $\mathrm{Gd}_{2} \mathrm{O}_{3}$ $\cdot 2 \mathrm{TiO}_{2}$, melts congruently at $1820{ }^{\circ} \mathrm{C}$. This phase apparently accepted up to about 3 mole percent $\mathrm{TiO}_{2}$ in solid solution at $1460{ }^{\circ} \mathrm{C}$. The unit cell dimensions of this pyrochlore structure type were found to vary from approximately $10.181 \AA$ to $10.169 \AA$. From x-ray powder diffraction data the equimolar compositions of either $\mathrm{Sm}_{2} \mathrm{O}_{3}$ or $\mathrm{Eu}_{2} \mathrm{O}_{3}$ with $\mathrm{TiO}_{2}$ were found to form phases which were very similar to both the low and high temperature modifications of $\mathrm{Gd}_{2} \mathrm{O}_{3} \cdot \mathrm{TiO}_{2}$. The composition $\mathrm{Dy}_{2} \mathrm{O}_{3}: \mathrm{TiO}_{2}$ apparently formed several phases one of which was apparently similar to the high temperature form of $\mathrm{Gd}_{2} \mathrm{O}_{3} \cdot \mathrm{TiO}_{2}$.

\section{References}

[1] S. J. Schneider, R. S. Roth, and J. L. Waring, J. Res. NBS 65 A (Phys. and Chem.) No. 4, 345-374 (1961).

[2] J. B. MacChesney and H. A. Sauer, J. Am. Ceram. Soc. 45, No. 9, 416-422 (1962).

[3] R. S. Roth, J. Res. NBS 56, No. 1, 17-25 (1956) RP2643.

[4] L. H. Brixner, Inorg. Chem. 3, No. 7, 1065-67 (1964).

[5] F. Queyroux, Bull. Soc. Franc. Mineral. Crist. 86, No. 3, 295-296 (1963).

[6] R. S. Roth and S. J. Schneider, J. Res. NBS 64A (Phys. and Chem.) No. 4, 309-316 (1960).

[7] R. Roy, I. Warshaw, and Y. Ukai, Third Quarterly Progress Report on Crystal Chemistry Studies. (Oct. 1, 1960-Dec. 30, 1960), File No. 40608-P-M-60-93-93, The Pennsylvania State University, 1-104 (1961).

[8] M. Perez y Jorba, Thèses Contribution à l'etude des systèmes zircone-oxyde de terres rares. Faculté Des Sciences De L'Université De Paris 1-33 (1962).

[9] Swanson and Tatge, NBS Circ. 539, Vol. I, 44 (1953).

[10] H. F. Stimson, J. Res. NBS 65A (Phys. and Chem.) No. 2, 139-145 (1961).

[11] S. J. Schneider and J. L. Waring, J. Res. NBS 67A (Phys. and Chem.) No. 1, 19-25 (1963).

[12] F. A. Mauer, Bridge-type Furnance Controller using Brown Servoamplifier, Informal Communiation; see also R. H. Bogue, Chemistry of Portland Cement, 2d ed. p. 311 (Reinhold Publishing Corp., New York, 1955).

[13] L. G. Wisnyi and S. Pijanowski, Metal Report of Tech. Dept., Mar., Apr., and May. U.S. AEC Publ. Kapl-1564, 19-20 (1956).

[14] C. E. Curtis and J. R. Johnson, J. Am. Ceram. Soc. 40, 15-19 (1957).

[15] S. J. Schneider, NBS Monograph 68 (1963),

[16] J. L. Waring and S. J. Schneider, Bull. Amer. Ceram. Soc. 43, No. 4, 263 (1964).

(Paper 69A3-344) 